\title{
Indigenous organisations and mining in the Pilbara, Western Australia: lessons from a historical perspective
}

\author{
Sarah Holcombe
}

\begin{abstract}
Summary
This paper traces the development of the first private company set up by Aboriginal people in Western Australia. This company, Northern Development and Mining (Nodom), was formed in the late 1940s to enable Aboriginal members of the company to develop an economic base from mining and pastoralism in the Pilbara region in north-western Australia. The methods by which this company operated and the impetus behind its formation, which stemmed from a pastoral strike and associated social movement, are instructive today. Nevertheless, this paper does not attempt to provide a comprehensive overview of this early movement and the associated companies of Pindan and Nomad. Rather, it aims to draw out and interrogate structural elements of these early organisations that can shed light on management issues of contemporary Indigenous organisations set up to harness economic and social development from major mines in the Pilbara region. As such, anthropological field research was undertaken to inform this contemporary project. Hence, the selective historical mapping within this paper focuses on the structure of leadership and the associated issues surrounding access to benefits within these early organisations. Questions are raised that will assist in the analyses and formulation of effective governance structures in this same region today. Researching the history of settlement and early development is an essential prologue to contextualising current Indigenous responses to mining and associated development.
\end{abstract}

\section{Introduction}

Over the last ten years in the Pilbara there has been a flowering of Indigenous organisations. Many of these have developed in response to land-use agreements, both commercial and under the Native Title Act, with mining companies for large-scale mining projects - principally iron ore. The wider research question for this project is to what extent the mining industry can contribute to the regional economy and wider social sustainability through its engagement with Indigenous stakeholders. As an anthropologist my research focus in this project involves the examination of the organisational structures set up by Indigenous groups to manage and disburse the potential benefits that flow from these land-use agreements. Access to publicly available written 
materials about these specific organisations is limited, and there is original material in this paper for which there are no published evidentiary sources. Hence, the anthropological research component of this paper is meshed with historical data. ${ }^{1}$

This paper investigates the common themes that emerge from these inter-cultural organisations from the 1940s to today, such as comparable issues of organisational structure, representation and leadership. Reflecting on the past is a fundamental method for considering the present situation. Thus, this analysis of the early organisations set up to harness commercial enterprise offers an instructive comparison with the contemporary situation.

There are two major aspects to this paper. First, it briefly sketches a history of the sociopolitical conditions of Indigenous people in this region, as these conditions led to the pastoral strike in the 1940s and the development of the first Indigenous company in Western Australia. This historical sketch indicates ways of tackling the research questions that are raised about the intersections of the state, the development bodies and Indigenous 'groups' and organisations. Second, this paper looks at lessons that can be learnt from early Indigenous organisations, the Nodom, Pindan and Nomad Companies, that were formed in the 1940s, 1950s and 1960s respectively for mining and pastoral ventures. Wilson and Rowley use the term 'movement' to describe the impetus behind these organisations. ${ }^{2}$ The terms 'Pindan social movement' and the 'Pilbara Aboriginal social movement' are often conflated. According to Wilson, behind these organisations was a 'reformist, highly organised, non-Millenarian, co-ordinated and, if consideration of the predominant value emphasis is added, egalitarian' agenda. ${ }^{3}$ However, the momentum of this principally ideological agenda slowed considerably for many of the early Indigenous founders. The 'split' in the early company, due to an internal leadership challenge causing two factions to emerge, and the subsequent reformation highlight some of the central issues. ${ }^{4}$

Strong trends emerge and permeate through to the present, particularly the issue of 'cash in hand' payments, indicative of tensions between individualism and collectivism. Perhaps surprisingly, there is a strong resonance in the ideologies behind these early companies, between the socialist ideology of the 1950s co-operatives and the contemporary liberal reformative ideology post-native title. In this context of 'development' through mining, both ideologies seek the economic experience to be an absolute, encompassing social and political process with a view to long-term benefit. The contemporary terminology for this ideology is expressed in terms of 'community benefit packages', where immediate expenditure and entrepreneurial activity, perceived as individualistic, short term and financially risky, have been actively discouraged under contemporary trust structures, such as that set up under the Yandi

1. This paper stems from background research undertaken for the Australian Research Council linkage project 'Indigenous community organisations and miners: Partnering sustainable regional development?' The industry partners for this project are Rio Tinto and the Committee for the Economic Development of Australia (CEDA).

2. Wilson 1961, 1980; Rowley 1970.

3. Wilson 1961: 388.

4. Read and Coppin 1999: 123. 
Land Use Agreement. However, this trend appears to be lessening because of Indigenous pressure.

This paper navigates between the competing accounts and perspectives on this early movement and resultant companies. Because this movement was so radical for the time, it has received significant attention from scholars in anthropology and history, and biographers of key Indigenous leaders involved, while an autobiography and a novel were also written. ${ }^{5}$ These not only provide a wide spectrum of perspectives, but often make it difficult to objectively assess the efficacy of these early companies in delivering to Indigenous people the economic and social freedom which they had sought. For instance, for Don McLeod, the non-Aboriginal man who facilitated the formation of these companies, a central vision driving these organisations was social justice through a strong socialist ideology. Hence, the companies operated as co-operatives. Some significant policy reforms that developed during this period in Western Australia are a direct result of the activism of these organisations, such as an increase in cash wages for Aboriginal pastoral workers. ${ }^{6}$ Ironically, the cost of pursuing many of these wider social justice issues left Aboriginal people who were directly involved worse off. Many of the court cases were paid for through their earnings. Workers did not receive cash wages, as the profits from the company flowed back into developing and maintaining the company infra-structure and fighting these larger battles. A significant number of Aboriginal company members did not find this financial arrangement equitable and raised questions about control of the 'cheque book' and the structure of the company that allowed this external ideology to dominate. ${ }^{7}$

Analysing this leadership structure and the interaction between McLeod and the Indigenous company members allows us to consider such issues as how his personal relationship with people influenced and drove their commitment and loyalty to the 'cause', the tensions between individual autonomy and the collectivity, and the diversity of expectations among the Aboriginal company members. Analysis of such issues is revealing of the types of governance structures for commercial enterprise that were instituted in this region in the past, and the types of men who became leaders. Likewise, analysing this early inter-cultural engagement can inform current research on Indigenous self-management in the same region. For instance, Wilson's ethnographic material from this early period suggests that economic success was achieved largely within an Aboriginal cultural framework. ${ }^{8}$ This conclusion, however, appears to be premised on an ideal perception of Indigenous communality and egalitarianism, which resonated with some members of the company more than with others. Hence, the divisions or 'split' within the group. 9

\section{Regional historical overview}

Unlike many other remote regions in Australia, there has been very little mission presence in the Pilbara. Pastoralists were active in opposing missions in the region on the

5. Wilson 1961, 1980; Rowley 1970; Attwood 2003; Palmer and McKenna 1978; Read and Coppin 1999; McLeod 1984; Stuart 1959.

6. Rowley 1970: 261.

7. Palmer and McKenna 1978: 108.

8. Wilson 1961, 1980

9. Read and Coppin 1999: 119-40. 
grounds that they would stymie land access, along with access to Aboriginal workers. ${ }^{10}$ As a result there were no reserves set aside for Aboriginal people during the 1940s to 1960s, as there were in the desert regions of Western Australia such as Jigalong and Wiluna. The discouragement of missions in this region indicated the responsiveness of the early Department of Native Affairs to the pastoralists as the major regional economic stakeholders. The State government actively promoted settler development in this resource-rich region, to the detriment of any independent advocacy for Aboriginal people in the Pilbara. There was no representative body, or mediating organisation, between Aboriginal people and developmental interests related to exploitation of the land. Relations between Aboriginal and non-Aboriginal people initially occurred through the pastoral industry, and according to Edmunds are now viewed by Aboriginal people nostalgically as 'when people lived in harmony'. ${ }^{11}$ While this view does not accord with the realities of the harsh indenture ${ }^{12}$ system that led to the strike action of the 1940s, it contrasts with the subsequent negative relations with the mining industry from the 1960s and which are now beginning to be addressed. ${ }^{13}$

Aboriginal people in the Pilbara are not strangers to mining. ${ }^{14}$ Gold was discovered at Nullagine (about 240 kilometres north-east of the Hamersley mines) in 1878, and alluvial tin four years later. By 1906 about 300 Aboriginal people were panning in these tin fields, and developing a small-scale subsistence economy by selling bags of alluvial tin and gold to the local storekeeper for flour, tea and sugar. ${ }^{15}$ In other cases the local policeman would buy the product at a lower price, at the threat of 'hunt[ing Aboriginal people] away from the gold country', and on-sell it. ${ }^{16}$ This early period of the Aboriginal alluvial mining economy was also the basis of the novel Yandy by Donald Stuart. ${ }^{17}$ It focused on this early Indigenous engagement with mining, the hardships faced on the tin fields, and the impetus for the pastoral strike. ${ }^{18}$ The author, Donald Stuart, was a 'special category officer' for the Department of Native Affairs and his account competes somewhat with McLeod's, as discussed below. ${ }^{19}$

These Indigenous miners introduced a technical innovation in the use of a traditional winnowing dish and container known as the yandy. This flattened dish enabled Aboriginal people to compete effectively with European miners on the tin fields. The fact that this type of mining was labour-intensive also meant many Aboriginal people

10. McLeod 1984: 68; Wilson 1980: 157.

11. Edmunds 1989: 21.

12. This indenture system was a contract between the employer and employee. In theory the employer could be fined for non-compliance with minimal conditions relating to food, clothing and health of employees. Aborigines were in turn obliged to remain with that employer (Wilson 1980: 153). This system has also been described as 'slavery', as freedom of movement was not possible and wages were either extremely low or not paid (McLeod 1984:60)

13. Edmunds (1989) discusses the early negative relations with the mining industry.

14. Likewise, the blue asbestos mining industry began at Wittenoom, in the Hamersley Ranges in 1940, where a significant number of local Indigenous people worked (PAIWP, cited in Day 2004). There is, however, very little published material about Indigenous involvement at Wittenoom.

15. Wilson 1980: 152; Stuart 1959: 38.

16. Stuart 1959: 38.

17. Stuart 1959. 
without formal training could be successful at it. Those most skilled in using the yandy were Aboriginal women, perhaps - it could be inferred - because of the implement's similarity to the winnowing dishes predominantly used by them. ${ }^{20}$ Women were employed equally, and in fact were so central to the mining operations of the Pindan Company that a child-care camp, known as 'kids camp', allowed them to work full time. $^{21}$ In this period before citizenship rights all able-bodied Aboriginal people worked in pastoralism or alluvial mining. ${ }^{22}$ Until 1967 Aboriginal people in the Pilbara still held 30 mining tenements in the northwest and 28 in the Eastern Goldfields. ${ }^{23}$ Later, however, the mineral leases were increasingly taken up by large mining companies and Aboriginal people became less able to compete.

\section{The development of Pilbara towns and subsequent impact on the Indigenous population}

The development of the Pilbara mining towns is, according to Edmunds, 'perhaps the most visible demonstration of the extent to which control over social as well as economic development was ceded by the State government to the mining companies in the interests of rapid and large-scale resource exploitation' ${ }^{24}$

The first town established in the region was Roebourne. It was founded in 1866, two years after the first white pastoralists arrived in the region. ${ }^{25}$ Today most of the population of this town of approximately 950 is Aboriginal. ${ }^{26}$ Until the 1960s, however, it was predominantly a non-Indigenous town operating as the administrative centre of the region, and until then authorities imposed strict controls on Aboriginal movements both to and from the town. With the decline of pastoralism in the 1960s and 1970s, ${ }^{27}$ Aboriginal people began moving into Roebourne and the surrounding area. During this same period, major mining companies took up tenements in the area, largely as a result of the lifting of the earlier trade embargo on iron ore in 1950s. (The trade embargo

18. The information I have about Donald Stuart is limited to Wilson's comments. He indicates that Stuart was employed by the Department of Native Affairs to "combat "white influences" in Pindan. He remained very antagonistic to McLeod' (1961: 105). Nevertheless Yandy, although written in the 1950s, is a surprisingly revealing account of Indigenous politicaleconomic life during that period. Stuart has a number of narrative voices that take us through the period that led up to the pastoral strike and through to the strike action. A perspective of one of the tin fields, Moolyella, narrated from the point of view of Aboriginal leader Dooley Bin Bin is as follows:

It always depressed him, the Moolyella tin field. A grave of his people. Here came the cast-off old men and women, the lame and the blind, the feeble and ailing, turned adrift by the station owners to live or die as best they might. Here to Moolyella, to gouge alluvial tin, working old ground with yandies, winning enough of the small heavy black pebbles every day to buy the meagre rations for the morrow, here to Moolyella to rot and die came Dooley's people in their old age. Their relative, close 'lations, helped them, but Poverty was the lot of all blackfellas, and hunger was always grinning its most wilddog grin at Moolyella (1961: 46).

19. Wilson 1961: 104.

20. Wilson 1980: 153. As the novel Yandy suggests, before the establishment of the Aboriginal mining companies, women were strongly compelled to mine for different reasons, as the alternative was prostitution. 'It is better to yandy all day, half hungry, than to eat the tin of beef that is the fee of lying on the ground under a whitefella while he slakes his thirst at your throat and grinds his loins heavily, hurtfully, at your cold dry body' (Stuart 1959: 36).

21. Wilson 1961: 141. 
had been placed on the export of iron ore for steel making, when it constituted potential infrastructural support for World War II.) Construction of large open cut mines commenced, together with company towns to house the influx of employees. ${ }^{28}$ The first major mine, Mt Tom Price, was opened in 1966 after the closed company town and port of Dampier were built for its workers in 1965. ${ }^{29}$ In 1968 the open town of Karratha was built and another mining company, Cliffs Robe River, constructed its own port and company town of Wickham. These new towns are respectively 38 kilometres and 12 kilometres from Roebourne. By the early 1970s there were nine closed company towns in the Pilbara: Pannawonica, Dampier, Tom Price, Paraburdoo, Newman, South Hedland, Goldsworthy, Shay Gap and Wickham.

These towns crystallised the economic and social marginalisation of the Aboriginal population. Roebourne became an Aboriginal town as its resources, including nonAboriginal service workers, were moved to neighbouring Karratha and Wickham. Karratha became the new regional administrative centre. One Shire Councillor suggested that the key reason for not simply expanding the existing town of Roebourne was that the new 'residents were worried that they would have to live with a large Aboriginal population'. ${ }^{30}$ In 1989, 80 per cent of the regional Aboriginal population of the Shire lived in Roebourne. ${ }^{31}$ Although today these new towns are becoming 'normalised', 'a euphemism for the regularization of municipal and community services' in the transfer of control from the mining sector, the Aboriginal population would appear to have little incentive to leave Roebourne, where Indigenous resources have been centralised. However, in the Central Pilbara, in the area of Tom Price and the Karajini National Park, a homelands movement has developed with the setting up of the Wakathuni, Billeri, Youngaleena and Wirrilimarra communities.

The history of blue asbestos mining and the establishment of the nearby town of Wittenoom in the Hamersley Ranges offers an interesting comparison to the establishment of the iron ore industry discussed above. Lang Hancock began mining asbestos

22. During the early stages of Nodom the local economy of Aboriginal people was particularly hybrid (as per Altman 2001), as reliance on the customary economy in the form of hunting was also important for subsistence. This amalgam of the customary economy with income from the mining economy continued throughout the life of the companies (Wilson 1961). This Indigenous skill in harvesting local food might have played an active role in maintaining the companies during the periods of poor mining profits.

23. Edmunds 1989: 48.

24. Edmunds 1989: 49.

25. Shire of Roebourne history web site http://www.roebourne.wa.gov.au/historyshire.htm Accessed 3/1/06

26. See http://www.roebourne.wa.gov.au/historyshire.htm.

27. Unlike alluvial mining, pastoralism had been an activity largely dominated by men. However, it had enabled Aboriginal families to continue to live on their country.

28. Edmunds 1989: 28.

29. Company towns were known as 'closed' as all the infrastructure and services were provided by mining interests for their employees and support services. As local and state government agencies did not service them, non-mining interests were not catered for. Thus, conversely, an 'open' town such as Karratha was developed by local and state government to service the broader region.

30. Edmunds 1989: 11.

31. Edmunds 1989: 13. 
fibres in 1936 in Wittenoom Gorge on Mulga Downs station and by 1947 a town was built nearby to service the mine. ${ }^{32}$ The mine functioned until 1966 with Aboriginal labour alongside migrant labour. Aboriginal station workers 'from Mulga Downs would come and go to the mine', many of whom were of the Banyjima language group working on their own country. They likewise lived in the Wittenoom township and continued to do so after the mine closed in $1966 .{ }^{33}$ While there was work for Aboriginal men and women in the mine, this is likely to be because most non-Aboriginals refused to do it. ${ }^{34}$ The conditions in the mine and the mill were described as 'appalling'. ${ }^{35}$ As is now widely known, Wittenoom became 'the greatest industrial disaster in Australia' with cases of mesothelioma, asbestosis and lung cancer still being diagnosed. ${ }^{36}$ No records of Aboriginal employment at Wittenoom were ever kept, and special screening and monitoring programs were not available to Pilbara Aboriginal people until $1994 .{ }^{37}$

Edmunds' research in Roebourne on the political economy of race relations up to the late 1980s provides a useful baseline for considering the wider context in which contemporary land-use agreements, such as Yandi, are negotiated. It reminds us how recently the mining industry and companies such as Rio Tinto have been actively engaged with Aboriginal people:

As one Hamersley Iron employee at Tom Price explained [in relation to setting up their operations in 1966], Hamersley had no problems with Aboriginal people because there were no Aboriginal organisations that had to be dealt with. ${ }^{38}$

The exclusion of Aboriginal labour was inherent in the planning of these new mines. The then Department of Native Affairs concluded that there were no employment opportunities for Aboriginal people, despite the fact that the iron ore industry, particularly in that early stage, was heavily reliant on non-skilled labour and despite Aboriginal people's early experience with mining. ${ }^{39}$ Between 1961 and 1981 the regional population increased by 1400 per cent because of this introduced workforce.

It seems that a key factor in the Indigenous political economy of this region was the absence of intermediaries in the form of missions, ${ }^{40}$ a focused Department of Native Affairs, ${ }^{41}$ or the introduction of statutory advocacy bodies for Indigenous land rights (as occurred in 1976 in the Northern Territory). Thus, Aboriginal people have had to act as their own advocates in pursuing their civil rights. Indeed, as Wilson noted, the gen-

\footnotetext{
Safetyline Institute-Worksafe Western Australia 1998.

Day 2004: 1.

34. Some of the workers sent to Wittenoom were part of the Commonwealth government policy to place new migrants for a period of two years in any work situation (Asbestos Diseases Advisory Society of Australia Inc, ADAS).

35. ADAS.

36. ADAS; Safetyline Institute.

37. PAIWP 1995: 9 in Day 2004: 2.

38. Edmunds 1989: 47. Hamersley Iron was a business unit of the Rio Tinto Group.

39. Edmunds 1989: 48.

40. Wilson observed that the only time the Western Australia government encouraged a mission in the Pilbara (in this case in the form of financial assistance), was when the Roman Catholic church set up an Aboriginal pastoral station and established a school at White Springs. This was a specific attempt to stop the Pilbara Aboriginal Social movement in the late 1940s. Wilson notes that although this mission operated for a while, it held little attraction for the strikers (1980: 164).
} 
eral desire for independence and autonomy was reinforced by early negative experience with the Department of Native Affairs. ${ }^{42}$ The Pilbara protest and subsequent Aboriginal companies challenged the authority and legal controls of the state over Aboriginal lives and, as Clancy McKenna stated, assisted them 'to play the white man at his own game' ${ }^{43}$ In relation to the development of large scale mining it has been observed that 'if [Aboriginal people] happened to be sitting down in a mission on the site of the [mineral] finds, their cases would [have been] pressed' ${ }^{44}$ As it was, Aboriginal people had to press the case for economic and social rights themselves. This was done initially in relation to the pastoral industry in the 1940s, followed by the development of Indigenous-owned commercial mining companies in the 1950s and pastoral companies in the 1960s.

One of the ramifications of this history of struggle for political and economic autonomy has been the fraught introduction of native title representative bodies under the Native Title Act 1993. The relationships that some Aboriginal people, both individually and as members of family groups, have fostered over the years with development interests in the region are stronger than their relationships with the new organisations designated to represent them (such as native title representative bodies or the Aboriginal and Torres Strait Islander Commission regional council). Because of this, and the diversity of Indigenous socio-histories, attempts to foster a regional approach to the Indigenous polity in the Pilbara region have a fraught recent history.

These different political environments of Native welfare in the 1940s and postnative title in the early 2000s have implications for Indigenous organisational solidarity. Comparing the politically oppositional environment within which these early companies emerged and the negotiated reconciliation environment of today, provides the opportunity to consider the possibilities of governance structures within the wider sociopolitical economy.

\section{Early Aboriginal political activism and organisations in the region}

From 1946 to 1949 Aboriginal people employed in the pastoral industry across the eastern Pilbara staged a series of strikes. ${ }^{45}$ The return to station work occurred only when demands for pay and better conditions were met. Some never returned but instead took up new economic opportunities. Because Aboriginal labour on these stations was indentured (in a legally binding contract, see footnote 1), strikers were arrested and

41. This state negation of responsibility dates back to the granting of statehood in 1890 when the transfer of authority of the local Aboriginal population from the British Colonial office to the state occurred. Immediately after this transfer there was a move to favour settlers' interests. Aboriginal permission to hunt over leasehold pastoral properties was repealed. The Aborigines Protection Board with its travelling inspectors visiting outlying regions was disbanded. Instead local police and magistrates were requested to add 'protection of Aborigines' to their usual duties, leading to greater local control by settler interests. The change was also evident in the funding for the administration and welfare of Aborigines. Whereas the colonial office had required that $1 \%$ of the gross revenue of the colony should be allocated in this direction, the new government cancelled the ruling (Wilson 1980: 154).

42. Wilson 1961: 186.

43. Palmer and McKenna 1978: 109.

44. Rowley 1970: 168-9.

45. Rowley 1970: 253-5; Wilson 1980. 
sentenced to jail terms, especially the strike leaders, who included Dooley BinBin, Peter Coppin, Clancy McKenna and Ernie Mitchell. It was also a punishable offence to 'entice' Aboriginal labour from stations and a number of Aboriginal people were arrested and jailed on this basis, including Clancy McKenna and Dooley BinBin. ${ }^{46}$ It is worth noting that this walk-off, or strike, happened 20 years before the Gurindji walkoff from Wave Hill station in the Northern Territory in 1966, which is now considerably more famous. However, unlike the Northern Territory, in the eastern Pilbara, 'there were widespread rumours that stations were likely to close down because of poor seasons and decreasing profits. The future of the station culture appeared insecure. The situation was highly conducive to the spread of a movement which offered an alternative' ${ }^{47}$ To co-ordinate this strike action a social movement developed that effectively introduced industrial bargaining techniques to a group that had been economically and socially disenfranchised, with only their labour with which to bargain.

The (recently deceased) Don McLeod was the non-Aboriginal facilitator for this movement. In his work as a prospector and miner, and to some degree in the pastoral industry, he had seen that Aboriginal people were grossly exploited by the settlers. While working at one of the stations he discussed his views with the Aboriginal man Kitchener - an indentured station worker - who turned out to be a senior ritual leader for the area. Kitchener told other Aboriginal people of this white Australian who spoke strongly of Aboriginal rights. McLeod was invited to a large ritual gathering where, according to McLeod, 23 language groups were represented. ${ }^{48}$ The strike was planned at this 1942 bush meeting, and took four years to gain shape and momentum. However, this 'movement' involved more than striking for better conditions from the pastoral industry; a mining company was also formed to co-ordinate what many Aboriginal people in the Pilbara were already doing. This company, Northern Development and Mining (Nodom), was the first Aboriginal-owned company in Western Australia. ${ }^{49}$ It grew rapidly from 1949, and between 1951 and 1953 there were 700 members of this company. ${ }^{50}$ However, as Wilson indicates:

This increase in size brought problems of co-ordination, and of inculcating the rules and practices which had been developed. Some found abiding by group decisions irksome. Also, the more casual kin-oriented groupings were having to be modified somewhat to meet the demands of the wider organisation. Previously, each small group worked largely as an independent economic unit. ${ }^{51}$

The following sections of this paper examine these increasingly complex management methods, to highlight the leadership structures and the role that McLeod played in the organisation.

\footnotetext{
Read and Coppin 1999: 69; Wilson 1961: 58, 68.

Wilson 1961: 385.

McLeod 1984: 40.

Read and Coppin 1999: 113.

50. According to Wilson, in late 1949 McLeod was asked by the senior law men to join the activities of the group. McLeod's active involvement had also previously been forbidden because of the regulation forbidding association between Aboriginals and non-Aboriginals. McLeod had been jailed under this law many times. He then provided his vehicle for the use of the group and began wolfram mining (Wilson 1980: 164).

51. Wilson 1980: 164.
} 
The company purchased Yandeyarra station (the country of a number of the key Indigenous leaders) and three other stations with profits from mining, and established a home for Aboriginal hospital outpatients at Marble Bar. As well as working Yandeyarra as a pastoral enterprise, the company built a hospital clinic and a school there. ${ }^{52}$ It centralised all income and worked on an 'all found' co-operative basis; providing for greater expenditure on capital and development work such as road building and purchasing equipment. ${ }^{53}$ This pooling of earnings for the 'common good' accorded with McLeod's ideology of communism. It was also one of the major factors focused on by the Council for Aboriginal Rights based in Melbourne, who were active supporters of McLeod's involvement in the company. ${ }^{54}$ For this same reason, however, many prominent Indigenous members of the company left, and the company split in 1959.

By late 1953 the company had lost $£ 30,000$ and was forced into liquidation by the state. The company membership dwindled to just over $300 .{ }^{55}$ This was due to prolonged litigation over mining claims, problems with contaminated ore and continuing disputes with the State Department of Native Affairs. McLeod robustly argued that this failure was 'due to the legal and administrative contrivances instituted by the State in order to break the spirit of the organised blackfellows'. ${ }^{56}$ The Department of Native Affairs sought to take control by setting up the 'Pilbara Natives Society' and selling off some of the company's assets, such as Yandeyarra station. ${ }^{57}$ Wilson states that 'many returned to the stations, where higher wages were now available, or [again] set up small independent [alluvial mining] groups around Marble Bar, Nullagine, or out from Port Hedland' ${ }^{58}$ The Pilbara Natives Society lasted less than two years, and within that time McLeod was asked by some of the previous members to assist in setting up another company.

The Pindan Company was formed in 1955 and by 1959 employed 300 Aboriginal people, approximately one-third of the Aboriginal people in the area of its operation. ${ }^{59}$ There were six work camps, an administrative camp and two others, mining for eight different minerals including tin, copper, wolfram, gold and manganese. ${ }^{60}$ They also

52. Although the school was built, their application to the Education Department for a teacher was rejected on the grounds that it would entice Aboriginal workers from other stations to move to Yandeyarra if they were keen to have their children educated, and because such a move would be seen as de facto acceptance of McLeod (Wilson 1980: 164-5).

53. Wilson 1980: 164.

54. According to Attwood (2003: 136), the 'Council for Aboriginal Rights owed its founding to connections between the Communist leadership of the North Australian workers union ... and communist party members in Melbourne ... in 1951 ... The original committee included two Clergymen and the basis of its support broadened during the 1950s but the key players were socialists, who always held the main positions'.

55. Rowley 1970: 255. By 1954 mineral sales were held up over prolonged litigation involving a joint mining venture with an Adelaide company. The group was supplying labour for the operation in return for monthly payments. When these fell in arrears, the Aboriginal labour ceased as well.

56. McLeod 1984: 109.

57. Wilson 1980: 165.

58. Wilson 1980: 165.

59. Wilson 1961: 136. During this period there were also approximately equal numbers of Aboriginal and non-Aboriginal people in this area, although non-Aboriginal people were concentrated near the towns and Aboriginal on the stations and mining areas. 
had a joint management arrangement with Sims, a metal purchasing company. Again, in line with McLeod's communitarian ideals, wage payments were minimal or, according to some such as Coppin, non-existent. This was apparently so that more equipment could be bought for the company. However, as had happened previously, and according to McLeod, with the encouragement of the Department of Native Affairs, a split formed, with those who sought higher wages opposing McLeod. ${ }^{61}$ The tension between the Department of Native Affairs and McLeod is a persistent theme in all of the written sources. However, the issue of wages as a cause of dissatisfaction was not necessarily related to the tensions with the Department. For instance, Clancy McKenna held the position that 'you've got to give people what they earn, and make the lazy ones get on - otherwise you just got a few workers and the rest are bludgers'. ${ }^{62}$ This split could also have been partly due to a lack of flexibility on McLeod's part, in his overriding commitment to the co-operative.

In the mid-1960s McLeod and his followers, principally desert people, formed the Nomads Company in the Roebourne area. This dichotomy between the desert and riverline/coastal Aboriginal groups was one of the major sources of conflict within the company and is an issue in the region today. Although the desert people outnumbered the riverline/coastal people by 2:1 in company membership, all the powerful positions were held by the riverline/coastal people. One reason for this was that riverline/ coastal people had a history of greater contact with Europeans and as a result had a greater command of English and business skills, while the desert people were stronger in terms of their knowledge of Indigenous law. ${ }^{63}$ In this context these differences could also be considered in terms of the riverline/coastal people tending toward individualism and autonomy, and desert people tending toward collectivity (see below).

By 1967 the Nomads Company was supplying some of the labour for the new mining developments at Port Hedland and maintaining itself through mining. The earlier Pindan movement continued to provide a voice for Aboriginal people in the Pilbara: its Aboriginal Director, Peter Coppin, gave evidence to the Select Committee on Voting Rights in $1961 .{ }^{64}$ However, he was not an active member of the company at that time, as he and Ernie Mitchell had set up their own company, the Mugarinya Pastoral Company. They had eventually re-acquired Yandeyarra and part of White Springs station through negotiations with the state government. It is now held by the Aboriginal Lands Trust. ${ }^{65}$ By the 1980s the Nomads Group, formed after the Pindan split, was based at Strelley pastoral station (to the south-east of Port Hedland), while the remaining members of Pindan group, also known as the Mugarinya group, had Yandeyarra station as their base.

\footnotetext{
Rowley 1970: 257.

McLeod 1984: 101-8.

62. Palmer and McKenna 1978: 108.

63. Wilson 1961: 205-7.

64. Rowley 1970: 169.

65. Wilson 1980: 166; see also McLeod 1984: 109.
} 


\section{What lessons can be drawn from the energy and structure of these early companies?}

McLeod himself claimed that the major impetus for the success of the Pilbara Aboriginal movements and affiliated companies was that it was their enterprise, not his. ${ }^{66}$ This is McLeod's perspective and this issue of ownership is a complex one. In fact, the company was referred to as 'McLeod's Pindan group', as he toured the east coast of Australia under the auspices of the Council for Aboriginal Rights to publicise 'what it called 'positive angles of how to improve the situation [of Aborigines], and realistic schemes of alternative ways of life" ${ }^{\prime 67}$ McLeod's vision for the company found resonance with this Council who, according to Attwood, saw co-operatives as an alternative to capitalist modes of production and believed they could provide a new economic basis, at least for tribal people. ${ }^{68}$

McLeod's facilitation demonstrates the crucial role of the outsider in developing schemes that bring together Indigenous and non-Indigenous interests. The political vision and energy of McLeod was essential in enabling Aboriginal people to have a voice during this early period. Although it is possible that a strike would still have occurred, it probably would have remained localised in its immediate impact. McLeod assisted the strike leaders to co-ordinate the strike action across many pastoral leases, as well as assisting in raising funds to do so. It was this early radicalism, when McLeod became a champion of Indigenous rights, that harnessed the loyalty of the key Aboriginal founders of the company. However, three of these four founding members of the company left it in the late 1950s because of McLeod's tight control over it and because, as Coppin argued, 'he wouldn't listen to nobody' ${ }^{69}$

McLeod's expertise lay with the mining enterprise, rather than pastoralism, and he was more of an idealist than a businessman. The later split in the company appeared to stem from the fact that the Aboriginal members were not significantly involved in the company's financial planning, and that McLeod channelled significant amounts of company profits into expensive legal battles. ${ }^{70}$ According to Coppin 'he also wanted to send money overseas to poor people' in his embrace of charitable causes. ${ }^{71}$ McLeod was regarded by the Indigenous company members as the 'book-keeper' and he held the purse strings tightly. The use of this term is indicative, however, because although bookkeepers were important on stations, they were also peripheral to daily and social activity. ${ }^{72}$ A significant tension developed between those wanting cash for their labour and those who were content with communal reward and with consolidating the company empire by purchasing more equipment. There is no doubt that in terms of

66. McLeod 1984: 99.

67. Attwood 2003: 143-6.

68. Attwood 2003: 146 .

69. Read and Coppin 1999: 133.

70. One of these court cases involved challenging the Act of Native Affairs in the High Court. The contention was that it was an Act of slavery and so contravened the anti-slavery Act passed by the English parliament in 1833. According to McLeod the High Court 'admitted that Blackfellows were slaves under the Act. However, it ruled that Western Australia being a sovereign state, had the right to enslave any one it wanted to, providing it passed the necessary legislation' (1984: 60).

71. Peter Coppin, pers comm 2003. 
influencing broader Indigenous policy issues this 'movement' was successful. However, it wasn't successful in immediately elevating people's standard of living, as Peter Coppin noted: 'I was with him for twenty years, and everything broken, no new anything. At least when we were on the stations we always had new boots. That's [partly] why we went against him'. ${ }^{73}$ There were also long periods when there was very little to eat. Wilson refers to 1955 as the 'starvation period' when the workers lived on kangaroo meat and water. ${ }^{74}$

The success of McLeod's earlier organisational strategies was based on long-term association with the organisation members, a build-up of trust and some understanding of Indigenous political structure. This, in turn, fed into Aboriginal commitment to the organisation. As noted, he didn't plan the early meetings, he was invited to them and was later invited to take an advisory role as company director. However, according to the biographies of McKenna and Coppin and discussions with Coppin and Allen, McLeod's role became far more than advisory. ${ }^{75}$

Nevertheless, this early movement, which led to the strike action and the formulation of the mining companies, had its own impetus: it was not formed solely in reaction to development, but created development opportunities. According to McLeod, the mining venture was at the forefront in the region in developing mineral deposits. ${ }^{76}$ Yet, these companies weren't formed for solely economic purposes, although economic independence was a major driver. Both the Nodom and the Pindan Companies were also sociopolitical movements with a broad and wide-ranging agenda that included not only employment, but also education, health care, housing and dispute resolution methods to deal with civil and domestic conflicts. As Wilson observed, 'life in the Group required more of a person's total participation than the 'station system" ${ }^{.77}$ Wilson, whose ethnographic research occurred during the rise of the Pindan Company of the late 1950s, rather than the earlier Nodom, found that Pindan was both a sociocultural unit and a 'political community'. ${ }^{78}$

There is no doubt that for a period of time Pindan functioned effectively and this is the focus of Wilson's thesis. ${ }^{79}$ It would be equally interesting, however, to have focused on the reasons for the demise of Pindan. Nevertheless, there is value in teasing out elements of the apparently successful structure as it existed for several years, and consider why it worked for some people and not for others. Why was it that Pindan could not be sustained as a 'socio-cultural unit'?

72. Wilson 1961. Wilson states that 'on pastoral properties, 'book keepers' kept accounts and did general secretarial work. Although important in the administration of the stations, socially they were peripheral to many of the activities '. He indicates that the Pindan members 'saw a similarity between McLeod's place in the company, and that of the station book keeper' (1961: 147, footnote).

73. Coppin, pers comm 2003.

74. Read and Coppin 1999: 117.

75. Palmer and McKenna 1978; Read and Coppin 1999.

76. Mcleod 1984: 101-4.

77. Wilson 1961: 114.

78. Wilson 1961: 118, 120; Wilson refers here to Weber 1946: 338

79. Wilson 1961 


\section{Dispersed governance}

'Better to be poor altogether, not jealous. Not good to be boss. ${ }^{\prime 80}$

Legally the Pindan Compa ny was owned by six Indigenous shareholders, plus McLeod and Elsey Lee. ${ }^{81}$ It was stated explicitly that no other Europeans could become legal members of the company. Officially the shares were held in trust for the general body of members, approximately 100 people, including the various camp bosses and committee members. As Wilson indicates, 'the expectation was that these members could control the actions of the shareholders, and if necessary withdraw them by majority status' ${ }^{82}$ However, this apparent simplicity belied the elaborate structure of formal leadership which was, according to Wilson, 'conceived as a broad based pyramid with those most influential occupying the peak and with other leaders diffused throughout the base yet remaining responsible to those above them'. Three of the six Aboriginal shareholders regarded as the three most senior men were known as directors: Ernie Mitchell, Peter Coppin and Coombie. According to Wilson all three were of the riverline 'group', were ceremonial site holders and law leaders. ${ }^{83}$ Parallels can be made with this type of Indigenous leader today. To gain legitimacy and some degree of authority it is not enough to have business acumen and a solid command of English, it is also essential to have credibility in the arena of Indigenous law.

There were 25 gang and camp bosses and at least nine technicians, who included mechanics and rock-drillers. There were in total 72 'committee' members (apart from the shareholders) and 26 'ordinary members' ${ }^{84}$ The committee member positions were equally divided between men and women. Although there were no Aboriginal women shareholders (or directors), interestingly, of the 14 women Wilson has listed in a table of individuals in the Pindan Company hierarchy, 12 are committee members; a higher proportion than the men, despited the overall roughly equal numbers of men and women who were committee members. ${ }^{85}$ Wilson has only listed those individuals regarded as 'important' in each of these roles, suggesting that women used the sphere of the committee to address issues of concern to them, while men occupied almost all of the other roles - including those of 'ordinary members'. He further indicates that wives of bosses were expected to be on the committee, providing they could fulfil their roles. $^{86}$

The mineral holdings of the first company, Nodom, operating between the late 1940s and early 1950s were based around 14 work camps. ${ }^{87}$ Under the new Pindan

80. Peter Coppin, pers comm 2003.

81. I am unsure of this non-Aboriginal woman's association with Pindan. However, it may be assumed that she was personally associated with McLeod.

82. Wilson 1961: 145.

83. Wilson 1961: 146.

84. Wilson 1961: 146.

85. Wilson 1961: 146. Wilson's table showing the Pindan Company hierarchy indicates that he has only listed 'important company members mentioned in the text', but there appears to be some inconsistency in the numbers of 'committee members' versus 'ordinary members' (1961: 146).

86. Wilson 1961: 148 .

87. Wilson 1961: 89. 
Company these were reduced to 12 camps, six of which were camps engaged in prospecting or mining. ${ }^{88}$ These camps also tended to be residential areas. The structure of re-formed Pindan was not significantly different from the original Nodom Company. The work gangs were relocated to keep up with the changing market, and the economic scope of activities widened to include fishing for pearl shell, shooting goats and kangaroos for hide, and collecting buffel grass seed for sale. ${ }^{89}$ These work camps operated as independent business units in terms of immediate localised decision making. Camp bosses were also work bosses in the smaller mining camps. The camp bosses held authority over each dispersed residential area and their approval had to be given before any official meeting could be held. As Wilson indicates 'except in emergency, Directors and shareholders could not issue orders contrary to those given by a camp boss on matters of settlement administration'. ${ }^{90}$ Thus, a pattern of dispersed governance and consolidated residence emerged.

The work camps were linked to the central community of Two Mile, just outside Port Hedland, which acted as the administrative centre. This early form of governance could be regarded as 'connected localism' or 'relational autonomy'. ${ }^{91}$ However, it is not strictly a 'jurisdictional devolution' model in the sense that Smith writes of it, as the major decision-making power was centralised with the six directors, most of whom lived in Two Mile. Although much of the daily governance was dispersed, authority had not devolved on all levels: the work camps were answerable to the central administration. Nevertheless, the concept of regionally dispersed and layered community governance operated as a means to mesh local authority with collective scope. ${ }^{92}$

The two senior Aboriginal directors, along with the chief technicians, lived at Two Mile. This was the acknowledged centre of the Pindan community, according to Wilson, and provided relative stability for the group even though many of the mining camps were impermanent. These camps were established within a well-known area defined in contemporary economic and social terms, rather than in classical cultural and sociolinguistic terms. Although there were 13 'tribes' or language groups represented in the membership of Pindan, the language of Nyangumarta, a coastal/riverline language, was generally adopted. ${ }^{93}$

One of the most striking aspects of the governance structure of Pindan was the lack of distinction between the operations of the commercial enterprise and of civil society, as this society consisted of company members. This structure fed into all aspects of Pindan member lives. If members were not happy with this all-encompassing way of life, they left or were asked to leave. Wilson recorded 14 such cases during his field research period. ${ }^{94}$ Teddy Allen was one of those who was asked to leave. He indicated that he was 'sacked' by McLeod in 1950 because he didn't pool all his earnings, when he

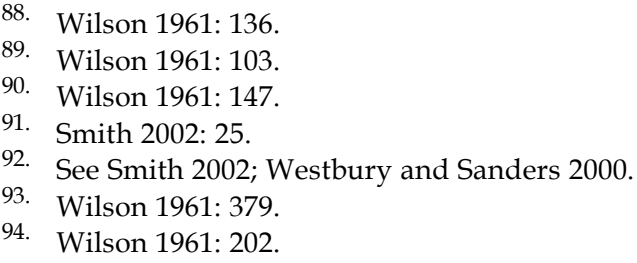


independently bought some clothes and other items with several others after selling buffel grass. ${ }^{95}$ Entrepreneurialism was not encouraged.

\section{Contemporary organisations}

Contemporary organisations, such as the Gumala Aboriginal Corporation and the Innawonga Banyjma Niapaili Corporation, established under land-use agreements, cannot operate in a similar holistic manner to these earlier organisations, although the agreements under which they are formed are comparably broad and encompassing. The Gumala Aboriginal Corporation was established under the Yandi agreement with Rio Tinto over three Hamersley Iron mines and associated infrastructure in 1997, ${ }^{96}$ while the Innawonga Banyjma Niapaili Corporation was established over the neighbouring BHP Billiton Area C mine and elements of its infrastructure in 2001. The Gumala Aboriginal Corporation has its head office in Tom Price with a sub-office in South Hedland, while the Innawonga Banyjma Niapaili Corporation has its head office in South Hedland, with two sub-offices in South Hedland and one in Roebourne.

Both Aboriginal corporations could theoretically have identical overlapping membership, as they are both based on the Innawonga Banyjma Niapaili native title claimant group of approximately 450 people. That the membership of both corporations is not consistent arises from a complex of individual political choice of affiliation with one or both corporations. This strategy is also associated with the differences in the structure of both corporations. Where the Innawonga Banyjma Niapaili Corporation has a centralised authority, with a non-elected Indigenous head who is also the head of the enterprise arm and the Trust, the authority structure of the Gumala Aboriginal Corporation is more dispersed. The GAC corporation holds annual elections for the chairman, the three different committees overseeing it, the enterprise arm and the Trust. The chairman is non-Indigenous. Both corporations have different establishment histories, tend to be associated with or dominated by different families within the three language groups (of Innawonga, Banyjima and Niapaili) and offer different benefits to the Indigenous stakeholders. In this sense they compete for allegiance.

The demographic pattern of Indigenous people today differs considerably from the time of the early companies, when those involved with the companies lived, by necessity, near the operations. Today Indigenous members of the Innawonga Banyjma Niapaili and Gumala Aboriginal Corporations live scattered across the Pilbara and beyond, far removed from the mine hinterlands. Within townships, families are scattered throughout the multiracial towns, and over the last 15 years a number of families have settled on outstations or homelands. Even when people are living in the same town, such as Tom Price or Paraburdoo, there is no 'community' ${ }^{97}$ of shared interests in fact, there is considerable diversity of interests. Most new corporation members do

95. Teddy Allen, pers comm 2003.

96. The infrastructure for the Yandicoogina project, for instance, is worth approximately $\$ 700$ million (Eggleston 2002: 3), while the land-use agreement as a package over 20 years is valued at $\$ 60$ million (Aboriginal Independent Newspaper 1998) or US \$40 million (Eggleston 2001: $10)$.

97. There is a considerable literature on the concept of 'community' and the value of it as a reference point for social structure. For two recent perspectives on the use of this term in the Australian Indigenous context see Holcombe 2004 and Sullivan 1996. 
not work in the mining industry in any capacity and, though many are in receipt of welfare entitlements, there is great diversity in Indigenous economic interests. Whereas the several dispersed business units were also residential units for these early companies, there is no contemporary comparable work place 'community'. Nevertheless, the structural framework of these modern land-use agreements, from which the Gumala Aboriginal and the Innawonga Banyjma Niapaili Corporations arose, remains broad as they attempt to capture, or perhaps create, an overarching paradigm that is as inclusive as the framework of the earlier companies.

The land-use agreements under consideration in this research project are complex and multifaceted. Rio Tinto views its agreements in the Pilbara, ${ }^{98}$ such as the Yandi agreement, as 'long term investments' through the introduction of 'a wide range of programs', which include 'taking responsibility for a wide range of social and cultural issues in the region'. ${ }^{99}$ A fundamental aspect of such an 'agreement benefit package' is that they are developed as social as well as economic investments 'under community trust structures, education, training and employment commitments, Indigenous business development, cultural heritage protection, environmental co-management and cross-cultural education, amongst other things' ${ }^{100}$ In fact, as these agreements attempt to reach into all aspects of Indigenous lives they could be interpreted as the attempted co-option of Indigenous parties to them, powerfully reminiscent of the earlier Pindan movement. Like the Nodom and Pindan trust structures, certain aspects of these modern trusts are dominated by external decision-making. Indigenous parties to the Yandi Agreement, from which the Gumala Aboriginal Corporation arose, have indicated that they have little control over how the money in the trust is distributed. Rather, as McLeod was 'boss for the cheque book', so the non-Indigenous Trustees of Gumala, based in Perth, are understood to operate. Since its inception in 1997, there has been a Gumala Trust rule that only 'community' enterprises will be funded (not individual businesses) and that cash payments are not offered to members. ${ }^{101}$ Thus, like the earlier companies, under the contemporary trust structure of Gumala, entrepreneurs tend not to be encouraged. Nevertheless, the structure of the Gumala Trust (known as the General Foundation) was the subject of review in late 2003 and the issues of cash payments and the types of businesses that could be funded were amongst the concerns of the review, according to Gumala members spoken with.

Modern multi-articulated Indigenous lifestyles equate to both dispersed residence and dispersed governance, the implications of which can only be touched on in this paper. With the expansion of business opportunities flowing from trans-national mining companies such as Rio Tinto and BHP Billiton operating locally, smaller groups of self-identified families and language groups are seizing the increased options in mak-

98. Another major neighbouring land-use agreement, which also covers three mines, is the Eastern Guruma Indigenous Land Use Agreement signed in 2002.

99. Van de Bund 1996: 1.

100. Harvey and Fry 2003.

101. The exception to this was the Foundation for the Elderly and Infirm which operated for the first four years of the agreement. This foundation or trust allowed those aged and infirm people a relatively small payment each year. After this fund expired, the demand for this payment to continue was such that the remaining General Foundation - under Gumala Investments - continues to provide the payment. 
ing agreements exclusive to those within the 'group'. The structure of this modern group is driven politically by the native title claim process; the process itself is divisive due to the administrative need to draw exclusive boundaries around claimant groups spatially and genealogically. The group then effectively becomes the negotiator for agreements with mining companies. Thus, there is no unitary Indigenous interest as may emerge through a representative body. Indigenous interests are dispersed over many agreements as the one family or language group may be party to several agreements, each of which varies in terms of its success in delivering benefits than other agreements. While on the one hand this enables dispersed and layered leadership from within families and language groups, it is also competitive and not necessarily in the interests of the Indigenous parties to the agreements. Ideally, a regional approach to standardising agreement-making could overcome factionalism that arises from this dispersed approach. Such an approach is being developed by the Pilbara Native Title Service, through the establishment of a negotiation protocol with Rio Tinto and the Fortescue Metals Group. A central negotiating committee, consisting of representatives of twelve native title groups, has been set up to meet with Rio Tinto to establish consistent regional principles. ${ }^{102}$

\section{Management of conflict}

'In conflict situations the source of authority becomes more explicit'. 103

One of the central organising principles that structured Nodom and the later Pindan companies was the management of conflict. Conflict 'permeated almost every aspect of group life' and thus meetings to deal with conflict regularly occurred. 'Directors learnt of the problems of ordinary workers and they in turn received reports of the [various camp] leaders' actions and future policies. Meetings were used to co-ordinate the work force and institute new mining units ... and [meetings were used for] settling conflicts' ${ }^{104}$ The impression from Wilson's material is that these meetings kept the operations open and transparent, but it is also clear that they were vital for maintaining order. As indicated earlier, casual kin-oriented groupings had to become more permanent and less contingent to meet the demands of the wider organisation, placing pressure on group members to maintain cohesion.

In light of Wilson's material in particular, a key theme to emerge over the many years of operation of these Indigenous companies has been the tension between autonomy or self interest and group or collective interest, and between equality and hierarchy. The encompassing framework of these companies is instructive of the processes that were implemented to impart information and to resolve disputes. The regularity of meetings was crucial in this regard as they kept a tight reign over the 'group' to maintain solidarity. If that was threatened, then the party involved was asked to leave.

\footnotetext{
102. Yamatji Marlpa Barna Baba Maaja Aboriginal Corporation annual report 2004: 50 and Ritter 2004.

103. Wilson 1961: 117.

104. Wilson 1961: 151.
} 
The committee system, as dispersed throughout all the mining camps and at the central camp, was the major forum for dispute management. The essential criteria for being a committee member was being 'able to "speak up at meetings", putting a viewpoint clearly and forcefully'. ${ }^{105}$ As indicated above, women tended to dominate this forum. They also held their own meetings every two days to decide on cooking duties and to air disputes between themselves. Unless these disputes were serious they did not reach a general meeting. ${ }^{106}$

The authority of the Pindan Company - principally held by committee members - also entered the realm of family disputes when they contravened camp rules or where the stability of the camp was at risk through domestic dispute. This included divorce meetings in order to annul a marriage in a formal yet amicable manner. ${ }^{107}$ In fact, Wilson notes that even as negotiations were breaking down at the company level when Pindan was splitting, 'the group techniques for dealing with kin and domestic matters affecting the community remained and were regarded as legitimate' ${ }^{108}$ It appeared that there was virtually no realm of camp life that was not under the purview of the company. For instance, a company director officiated at the weddings of company members, as well as at their divorces. ${ }^{109}$ Wilson also compares the structure of conflict resolution in law meetings with the secular meetings of Pindan. However, as he indicates, there are more reference to precedents and rulings in law decisions by senior ceremonial leaders. ${ }^{110}$ Judgments for secular decisions were, nevertheless, strong as 'persistent failure to abide by Pindan rulings resulted in warnings which, if not heeded were followed by expulsion'. ${ }^{111}$ This monopoly over the punitive regulation of behaviour resonates with the structure of a 'total institution' in terms of it being all encompassing and reformative. I am not asserting here that the Pindan Company was in any way like a prison; ${ }^{112}$ it was, of course, voluntary. However, the issues of maintaining social order and control were central to the daily operations of the camps as they consisted of company members.

One of the most common issues to emerge among contemporary organisations is the tension between 'too many meetings' and not enough of them. The old adage of 'if there is an information vacuum, then gossip and innuendo will soon fill it' is important to consider here. Thus, the regularity of meetings to maintain the effective running of these early companies was crucial in spreading knowledge, as well as in giving people the opportunity to voice their concerns. It seems apparent that a major element of the purpose of the structure of these early companies was this venting of conflict and asser-

\footnotetext{
105. Wilson 1961: 148.

106. Wilson 1961: 152.

107. According to Wilson 'marriage ceremonies in Pindan followed a modified Western pattern. The couple intending to marry 'put up' their request at a meeting where the kin clusters of the two persons discussed the matter. Unless there were irregularities such as 'crooked' [kinship] sections, or one of the applicants was already married, the acceptance was officially automatic' (1961: 173).

108. Wilson 1961: 286.

109. Wilson 1961: 173.

110. Wilson 1961: 191.

111. Wilson 1961: 191.

112. See Foucault 1977; Ignatieff 1983.
} 
tion of control. The need to maintain cohesion in the contemporary organisations of the Gumala Aboriginal Corporation and the Innawonga Banyjma Niapaili Corporation is no different. However, with membership scattered so widely, additional means are also necessary. Newsletters are produced by both organisations updating members on projects and programs funded. In the Gumala Aboriginal Corporation's case, their regional radio station - the Gumala community radio station - operating through the corporation office in Tom Price, acts to inform members (and the region generally) about the activities of the corporation.

\section{Structures of authority and leadership}

Wilson indicates that many of the leaders prominent in the camps and work gangs of the original company in 1952 remained influential figures in the re-constituted Pindan Company of $1959 .{ }^{113}$ Thus, there was considerable continuity of leadership over the life of the organisation. But, importantly, these leaders left when Pindan failed to offer them the responsibility and decision-making powers that they felt were necessary. They broke away, taking most of the original company membership and developed organisations that catered to their ambitions. ${ }^{114}$ For example, Peter Coppin and Ernie Mitchell split from Pindan to start Yandeyarra station through the Mugarinya Company, ${ }^{115}$ while Clancy McKenna had left earlier over the payment of wages.

Nevertheless, highly structured lines of authority operated over the span of Nodom and Pindan. Authority appeared to be diffused throughout the company by the institution of the 'committee', which not only automatically encompassed the formal leaders, such as the six shareholders, but also included forceful persons effective in administrative matters with no official leadership position. 'Spokespersons emerged at times of crisis within the Group when factions developed [and equally they] could be withdrawn if the group sponsoring [them] agreed that [they] were not adequately stating their case' ${ }^{116}$ The fact that the almost half of the committee members were women, and they were the most 'important' on the committee, suggests that women played a greater role than has been formally acknowledged.

Wilson notes that the person had to fit the role. ${ }^{117}$ The six Aboriginal shareholders 'were recruited in a manner which combined features of appointment and election ... [It] bore some similarity to the technique used by [Aboriginal people] to introduce new Law men. Eligible persons were nominated by leading members and the candidate's suitability was discussed'. This formal and transparent election process offers parallels with IM Young's critique of democratic process in Iroquois federalism:

Leaders were chosen on merit, although they usually came from designated families; they were expected to respond to public opinion, and in extreme cases could be impeached if they abused their power; issues and policy proposals could come from anywhere in the federation; decision-making relied on deliberation both within and among member nations and included mechanisms of review. ${ }^{118}$

\footnotetext{
113. Wilson 1961: 90.

114. Read and Coppin 1999: 119.

115. Palmer and McKenna 1978: 119

116. Wilson 1961: 148.

117. Wilson 1961: 146.

118. Young 2000: 241.
} 
Although its scale is different, Young's brief summation of Indigenous North American democracy allows us to consider Pindan as a comparable form of decision-making.

The limitations on power within this structure were an issue for Pindan. Wilson indicates that 'it was recognised that leaders in one sphere tended to have power in another, even though they might have no actual [formal legal] authority'. ${ }^{119}$ 'Ritual leaders' who had experience on pastoral stations were powerful within these new organisations. However, as Wilson states,

Those from influential kin clusters had a greater chance of getting leadership positions. As the riverline people 'owned' the land and their middle aged and elderly men as a group were more acculturated in Western ways than the equivalent Desert men, they had become predominant in the top leadership positions in the Company. ${ }^{120}$

As noted above, those in leadership positions were also the ones to leave. The range of leadership roles was based on the ability of the individual to act as a public spokesperson and to be 'reasonable'. ${ }^{121}$ Peter Coppin also used this term 'reasonable' and indicated that it 'required listening carefully to a lot of information from people in groups and then coming to what was essentially a compromise decision' ${ }^{122}$ Thus, leadership was not based solely on traditional criteria, such as a ceremony leader or country owner, but importantly also on leadership skills and technical knowledge. ${ }^{123}$

Wilson's ethnography of this early movement also traces the rise of the 'young men' into positions of power. Many of these had worked as independent contractors for mines or pastoral companies before joining the company. A significant number of them were so-called 'part Aboriginals', 124 including Mitchell, Coppin and McKenna. These people were adept at operating in the European business world, but were also committed to their Indigenous business world of ritual. Wilson indicates, however, that a recurring problem in the issue of leadership was that 'there were insufficient high status positions in the company for those who desired them, especially for the young men, more acculturated in Western ways' ${ }^{125}$ This was the case even with the possibility of

119. Wilson 1961: 204.

120. Wilson 1961: 204. Wilson indicates that Pindan was made up of 13 different 'tribal' groups and migrants from others. They were not equally represented. The most numerous Njangomada [Nyangumarta] with 156 people, outnumbered the next largest 'tribal' grouping, the Njamals [Nyamal] with 42 people, by about 4:1. More broadly, these 13 groups were classified by the people themselves into 'riverline' and 'desert'. Taken as a whole the desert people of the Pindan outnumbered the riverline by 2:1 (Wilson 1961: 154). However, as discussed, the riverline people held the majority of the leadership positions.

121. Wilson 1961: 188.

122. Read and Coppin 1999: 116.

123. Wilson discusses the shortage of technicians as an element in the early failure of Nodom. The company relied on a few people who were sufficiently expert in supervising the mining operations. When one of them happened to fall ill at a crucial time - when a shipment was due - the commercial vulnerability of the company was exposed. The issue of the level of education and technical capacity of the company members is acknowledged as crucial to the company's success, as was the training of apprentices. Wilson mentions that there were four apprentice mechanics in Pindan (1961: 150).

124. The term 'mixed descent' was used to refer to Clancy McKenna in his biography (1978), while Rowley (1970) tends to use the term 'part-Aboriginal'. 
several positions at the top. And, as discussed, the reality was that McLeod was 'the boss', with the final say on the financial direction of the company.

Direct parallels can be seen today in the fission and fusion of Indigenous organisations, while the leadership of key people continues. For instance, in the early negotiation and development of the Indigenous organisations set up to manage major land-use agreements over the last 10 years, the same individuals tend to hold the powerful roles. The first chairperson of the Gumala Aboriginal Corporation, set up under the Yandi Agreement, played a major role in developing it and clearly learnt a lot from the process, describing the negotiation of this agreement as a 'learning curve'. He then went on to found the Innawonga Banyjma Niapaili Corporation which effectively competes with the Gumala Aboriginal Corporation in some key areas, although as indicated there is a significant overlapping of membership. The point is that this fission of organisations and leadership is dynamic, as opportunities are sought out.

There are direct parallels with the ideologies behind the Gumala Aboriginal Corporation and the earlier Nodom and Pindan Companies, with their collective refusal to offer cash payments to members. It is arguable that, like the earlier companies under the directive influence of Don McLeod, it was also the primarily external influences of Rio Tinto that directed the trust structure of the Gumala Foundation in not allowing cash payments to members. Interestingly, the more recent Innawonga Banyjma Niapaili Corporation was established with different rules that include the possibility of limited cash payments to individual members. This is an important difference between the two Indigenous organisations and is often commented on by their respective overlapping beneficiaries.

It is also worth noting that this schema of collectivity, referred to now as 'community', appears to have its strongest advocates externally. Recall the 1950s Council for Aboriginal Rights perspective on Pindan as a co-operative. Is there a perception that the collective approach to money is the best way for Aboriginal people to deal with the wider economy? This approach is not necessarily shared by Indigenous people themselves. As recalled by Wilson for the early companies, 'although the ideal remuneration scheme for the Group was a collective one, since its inception there had been spasmodic attempts to introduce "cash in hand" payments'. ${ }^{126}$ Like the earlier leaders Ernie Mitchell and Peter Coppin, the original chairman of the Gumala Aboriginal Corporation also listened to the broader opinion and was strategic in forming another corporation with the ability to offer its members some immediate returns.

\section{The company as an inter-cultural phenomenon}

Wilson conceptualises those who act as spokespersons for the company as 'bridgemen', 127 linking the company with 'outside authority and interpret[ing] events for members of all systems'. He indicates that kinship and law systems were integrated with the company. It is important to note that the men with authority were Law men, as well as technical experts. They had to be both, to operate effectively and legitimately in this 'inter-cultural' arena. ${ }^{128}$

\footnotetext{
125. Wilson 1961: 199.

126. Wilson 1961: 203.

127. Wilson 1961: 123.
} 
The importance of continuing the Law during the operation of the early companies was stressed by the Aboriginal company members. ${ }^{129}$ As McKenna stated to McLeod when he chose to leave Nodom, 'we Marangu just about forgotten our business. You told us once we got to leave all that law behind us, if we ever going to make anything. Well, I reckon that was a wrong thing'. ${ }^{130}$ However, on the other hand Coppin indicated that "throughout the strike and even after ... "the Split", the elders continued to do the Law'. ${ }^{131}$ This may have been without the encouragement of McLeod, however.

The fact that McLeod controlled the finances was also a major issue. In this key area there were strong perceptions that McLeod was not being accountable, and that the maintenance and expansion of the company infrastructure was not transparent. As Peter Coppin noted, 'people were signing cheques, but for what?'132

Attwood notes that the Council for Aboriginal Rights saw Pindan as a 'half-way house to full assimilation'. ${ }^{133} \mathrm{He}$ argues that it was perceived 'as a means rather than an end in itself ... instead of an example of an ongoing state of cultural difference and of a minority group claiming rights as a group'. It seems to me that neither perception is reasonable, as both radically underestimate the extent to which Pindan and the associated movements meant different things to different participants. The diversity of expectations by its Aboriginal members of what it could deliver to them was significant. This diversity was informed by language, culture and history. For many, the companies were vehicles to gain equality, so they could operate like other citizens. Clancy McKenna, for instance, left Pindan as he 'felt that the strike was now behind him. He had won for himself at least, the right to work, and keep a job like a white man. Now he wanted to be a success, to be a boss, and to earn money like other white men did'. ${ }^{134}$ Those who stayed with McLeod and formed the Nomad Company were operating less individualistically and were content to be part of a group by following the leadership of McLeod. These were principally the desert Aboriginal people. Today, this corralling of so-called 'Indigenous interests', where people have to operate in the interests of the group - through the vehicle of the elusive 'community' - is a strong pattern in the development discourse. ${ }^{135}$

When the company split, it is noteworthy that it followed the cultural and regional divide of riverline/coastal and desert. As Wilson indicated, 'kin affiliations affected loyalties, the coastal 'riverline' people tending more to support Mitchell and Coppin, the desert people to be in sympathy with McLeod' ${ }^{136}$ However, overarching kin affiliations were the different histories and expectations that Aboriginal people

128. See Holcombe 2005; Martin 2003; Merlan 1998. Inter-cultural theory has an extensive literature within post-colonial studies internationally, in particular, the work of Bhabha and his concept of the 'third space' (1995) and Brathwaite (1971) on creolisation in Jamaica.

129. Palmer and McKenna 1978.

130. Palmer and McKenna 1978: 109.

131. Read and Coppin 1998: 142.

132. Peter Coppin pers comm 2003.

133. Attwood 2003: 147.

134. Palmer and McKenna 1978: 105.

135. See in particular Nussbaum 2001 and Escobar 1995.

136. Wilson 1980: 165. 
brought with them from these regions. As indicated earlier, the fact that Aboriginal leaders were from the coastal/riverline groups indicates that they brought with them qualities gained from their work as contractors, based on a history of interaction with settler enterprise. This raises the question of whether or how the companies were culturally based, as they clearly did not comprise a coherent or homogenous Indigenous 'group' derived from pre-contact group structure, however relational and contingent this group may have been. Several of the key leaders, such as Peter Coppin and Clancy McKenna were not driven by the mining enterprise but - like many of the other coastal/riverline people - 'preferred instead the stock and horse work that [they] had grown up with and become so adept at' ${ }^{137}$ There was a tendency in the 'split' for the coastal/riverline people to have shared a history in pastoralism, while desert people were more closely affiliated with mining as the more dominant economic opportunity in the desert region.

The composition of the contemporary organisations offers an interesting contrast to these earlier ones as the latter were defined in pragmatic economic and socio-historical terms. As mentioned previously, the membership of the contemporary Aboriginal corporations such as Gumala and the Innawonga Banyjma Niapaili Corporation established under land-use agreements is politically defined in cultural terms under the Native Title Act 1993. Each negotiating body comprises a native title claimant group, thus defining Indigenous 'groups' in terms of shared language and land. This apparently convenient collectivity belies the negotiation that takes place within and between families, where this group is as contingent as siblings deciding to 'follow' their mother or their father for membership to different groups. The contemporary membership of these new organisations may be just as contingent as it was during the earlier period, when the issue of cultural groupings was on a much more regional scale and quite dependent upon individuals simply wanting to be involved.

\section{Conclusion}

The application of a historical framework to this contemporary research project is vital. In this Pilbara case study, there is a precedent for significant Indigenous engagement in commercial development through the mining industry (unlike in the Northern Territory, for instance). This early engagement was vigorous and lasted for over 20 years, allowing for change and development. Although this project is dealing with some new issues in terms of Indigenous partnering with large development companies, some of the key issues remain unchanged. The language of engagement may have changed from the Indigenous companies of the 1950s and 1960s to the post-native title present, but central aspects of the ideology underlying the engagement in these two periods are shared. The language has shifted from discussion of 'co-operatives' to 'communities', from 'egalitarian non-capitalist reform through a new economic basis', 138 to 'long term investments under community trust structures' ${ }^{139}$ The ideology behind both is allencompassing, seeking the complete immersion of the Indigenous polity to the regional mining agenda.

\footnotetext{
137. Read and Coppin 1998: 134.

138. Attwood 2003: 146; Wilson 1961.

139. Harvey and Fry 2003.
} 
This paper's preliminary comparative historical analysis has identified patterns that have emerged in the Indigenous engagement with enterprise in the Pilbara region. These patterns could be considered as principles of engagement in this inter-cultural context. Such principles include the role of the outsider, which in the case of Don McLeod was crucial in facilitating the establishment of these early companies. This is not to suggest that outsiders are always 'crucial' to developing Indigenous entrepreneurial enterprise, although external influences may often be necessary to initially facilitate change. Nevertheless, the extent to which this external agent stays engaged in the enterprise may depend on whether their role, which is likely to be in the area of financial management, is charged with 'listening' to and engaging with their constituency, or, in the contemporary case, the agreement beneficiaries.

There are tensions between the issue of maintaining the collectivity and the desire of individuals for autonomy. This manifests most clearly in the desire for cash in hand, rather than pooling for collective or 'community' benefit. Another aspect of this is the issue of transparency. When one receives cash, there is an immediate return and in this exchange, an understanding of where, or at least how, the money has been distributed. A lack of visible monies can be alleviated by keeping people informed and including them in the 'bookkeeping' process, rather than allowing it to be left to, or dominated by, the external agent. There is an interesting resonance here with the issue of cash wages in the early companies and cash payments by contemporary mining companies, which were not perceived as a sound long-term investment.

Another emerging trend is that leaders who want a long-term career have to 'listen' to their constituency and appear 'reasonable', which may also be a way of referencing majority perspective on an issue. If one takes as an example the cash in hand issue, this concession to the majority may appear problematic to external audiences. Nevertheless, it would appear that successful Indigenous leadership has to recognise and acknowledge the diversity of Indigenous interests and attempt to balance this against majority interests, while also being aware of, or referencing, external interests and expectations. This results in a complex set of tensions. ${ }^{140}$

The continuity of leadership and the types of men who become leaders has emerged as another pattern. In this inter-cultural context, leaders must not only be adept in the realm of commercial business, but have to be respected and have credibility in the religious context of local Indigenous Law. They cannot have expertise solely in this area - they must have both abilities. The degree of expertise or knowledge in this area of law is, however, the most critical, and is debated amongst their constituents. The two realms of expertise sit in tension throughout the period of leadership. Furthermore, if the ambitions of these leaders cannot be met, then new opportunities will be created or seized in this cycle of the fission and fusion.

The tensions between the larger ideological issues, such as social justice for all Aboriginal people in Western Australia, ${ }^{141}$ and the on-ground issues of achieving a decent standard of living for those who worked for the early companies, ${ }^{142}$ were

140. See also Dodson 2003 and Kilgour 2003.

141. McLeod 1984.

142. Read and Coppin 1999. 
significant during the early movement. A key theme to emerge is that tangible positive change in terms of addressing immediate needs has to be evident to maintain loyalties, and this is equally true for contemporary organisations.

In this contemporary context not only is the wealth (noting that the Yandi agreement is worth $\$ 60$ million) and thus the planning for its expenditure more significant, but mining companies also seek outcomes from their community program inputs, as the new era of corporate social responsibility embraces concepts such as 'sustainability' ${ }^{143}$ The Rio Tinto Aboriginal Training and Liaison program in 2000 evaluated the 'tradeoffs between culture and independence' as a threat in a SWOT (strengths, weaknesses, opportunities, threats) analysis. ${ }^{144}$ This perspective could be considered in light of the legalistic and restrictive framework under which the Native Title Act 1993 is implemented, which (to over-simplify) emphasises the need to demonstrate adherence to tradition, and the practice of customary law and the continuity of attachments to land. It is arguable that this has encouraged a renaissance of tradition. At the same time this contradicts the policy agenda of 'mainstreaming', which emphasises engagement with the formal economy as exemplified by land-use agreements. Yet, land-use agreements sit uncomfortably in this recognition space. This is because agreements, such as Yandi, are structured around a communally-based benefits package with an emphasis on trust structures and a discouragement of entrepreneurial activity. They seek to mesh with the renaissance of tradition through the development of a neotraditional communitarian economy.

\section{Acknowledgements}

This paper derives from a paper given in the Centre for Aboriginal Economic Policy Research seminar series, a pre-fieldwork paper for the Australian Research Council project 'Indigenous community organisations and miners: partnering sustainable regional development?'. The focus of this project is the implementation of land-use agreements and the effectiveness of benefit flows to the Indigenous recipients. I have undertaken three periods of field research (over two months) in this Pilbara region since the seminar paper was presented, and have considerably re-cast the original paper in the light of this experience. The first field-site of this multi-site project is the Rio Tinto Hamersley Iron and Robe River mines in this region. I would like to thank Jon Altman, David Martin, David Trigger, Julie Finlayson, Robert Levitus, Bruce Harvey and Elizabeth Bradshaw for their comments on this paper. I would like to thank Peter Coppin and Teddy Allen for their patience in recollecting their early experiences with the mining co-operatives during a visit to their respective homelands. And finally, an important thanks to the many Indigenous parties to the contemporary agreements who I and other colleagues interviewed in Tom Price, Wakathuni, Billeri, Youngaleena, Port Hedland, Wickham, Roebourne and Karratha. They remain anonymous for the purposes of confidentiality.

\footnotetext{
143. See Eggleston 2002; Horwood 2002.

144. Dames and Moore 2000.
} 


\section{References}

Aboriginal Independent Newspaper 1998, '\$60 million Gumala Yandi ahead of schedule', 27 May: 5.

ADAS (Asbestos Diseases Advisory Society of Australia Inc) http:/ www.asbestosdiseases.org.au/asbestosinfo/wittenoom_tragedies.htm, accessed $10 / 1 / 06$.

Altman, JC 2001, 'Sustainable development options on Aboriginal land: the hybrid economy in the twenty-first century', CAEPR Discussion Paper 226, Centre for Aboriginal Economic Policy Research, Australian National University, Canberra.

Attwood, B 2003, Rights for Aborigines, Allen and Unwin, Sydney.

Bhabha, H 1995, 'Cultural diversity and cultural differences', in B Ashcroft, G Griffiths and $\mathrm{H}$ Tiffen (eds) The post-colonial studies reader, Routledge, London and New York.

Brathwaite, E 1971, The development of Creole society in Jamaica 1770-1820, Clarendon Press, Oxford.

Dames and Moore 2000, 'Evaluation of aboriginal training and liaison program', Draft report for Hamersley Iron Limited, March, Adelaide.

Day, W 2004, 'Banyjima people and asbestos mining: the case of Wittenoom Gorge', unpublished manuscript prepared by Bill Day while working for the Gumala Association, held by the author.

Dodson, M 2003, 'Capacity development for Indigenous leadership and good governance', conference paper at 'Building effective Indigenous governance', Jabiru, 4-7 November 2003.

Edmunds, M 1989, They get heaps: a study of attitudes in Roebourne Western Australia, Aboriginal Studies Press, Canberra.

Eggleston, P 2001, 'Social responsibility of mining companies as a business efficiency factor: communities, human beings and the environment, an international view', paper at 'Brazilian mining' conference, Belo Horizonte, 25 April 2001.

- 2002, 'Gaining Aboriginal community support for a new mine development and making a contribution to sustainable development', conference paper at 'Energy and resources law 2002', Edinburgh Scotland, 14-19 April.

Escobar, A 1995, Encountering development: the making and unmaking of the Third World, Princeton University Press, New Jersey.

Foucault, M 1977, Discipline and punish, transl A Sheridan, Allan Lane, London.

Harvey, B and Fry, E 2003, 'What cost native title?' Speaking notes for MCA Sustainable Development Conference, 12 November 2003, Brisbane.

Holcombe, S 2004, 'The sentimental community: a site of belonging - a case study from central Australia', Australian Journal of Anthropology 15(2): 163-84.

- 2005, 'Luritja management of the state', in M Hinkson and B Smith (eds) Articulating cultures: the local, the global and the intercultural in Indigenous Australia, Oceania Monograph 75(3): 222-33.

Horwood, B 2002, 'Reputation and license to operate', conference paper at 'Energex Futures', 2 October 2002. 
Howard, MC 1978, 'Whitefella business': Aborigines in Australian politics, Institute for the Study of Human Issues, Philadelphia.

Ignatieff, M 1983, 'State, civil society and the total institution: a critique of recent social histories of punishment', in D Sugerman (ed) Legality, ideology and the state, Academic Press, London.

Kilgour, N 2003, 'Future leaders: developing and sustaining their contribution to good governance', conference paper at 'Building effective Indigenous governance', Jabiru, 4-7 November 2003.

Kolig, E 1989, 'The powers that be and those who aspire to them: power, knowledge and reputation in Australia Aboriginal society', in JC Altman (ed) Emerging inequalities in Aboriginal Australia, Oceania Monograph 38, University of Sydney, Sydney: 43-65.

Martin, DF 2003, 'Rethinking the design of Indigenous organisations: the need for strategic engagement', CAEPR Discussion Paper 248, Centre for Aboriginal Economic Policy Research, Australian National University, Canberra.

McLeod, D 1984, How the West was lost: the native question in the development of Western Australia, published by the author, Port Hedland, WA.

Merlan, F 1998, Caging the rainbow: places, politics and Aborigines in a north Australian town, University of Hawai'i Press, Honolulu.

Nussbaum, MC 2001, Women and human development: the capabilities approach, Cambridge University Press.

PAIWP (Pilbara Asbestos Injuries Working Party) 1995, 'Pilbara Asbestos Injuries Research Project - final report', unpublished report held by the author.

Palmer, K and McKenna, C 1978, Somewhere between Black and White: the story of an Aboriginal Australian, Macmillan, Melbourne.

Read, J and Coppin, P 1999, Kangushot: the life of Nyamal Lawman Peter Coppin, Aboriginal Studies Press, Canberra.

Ritter, D 2004, “"Don't call me baby”: ten years of the Yamatji Marlpa Barna Baba Maaja Native Title Representative Body', Indigenous Law Bulletin 6(6): 4-6.

Rowley, CD 1970, The remote Aborigines, Australia National University Press, Canberra.

Safetyline Institute-Worksafe Western Australia http:/ / www.safetyline.wa. gov.au/institute/level2/course21/lecture95/195_04.asp, last updated 5 May 1998, downloaded 9 December 2004.

Smith, D 2002, 'Jurisdictional devolution: towards an effective model for Indigenous community self-determination', CAEPR Discussion Paper 233, Centre for Aboriginal Economic Policy Research, Australian National University, Canberra.

Stuart, D 1959, Yandy, Georgian House, Melbourne.

Sullivan, P 1996, All free man now: culture, community and politics in the Kimberley region, north-western Australia, Report Series, Australia Institute of Aboriginal and Torres Strait Islander Studies, Canberra.

Van de Bund, J 1996, 'An analysis of a successful training and employment program with a major mining company', conference paper at 'Doing Business with Aboriginal Communities', 27-29 February, Darwin.

Weber, M 1946, From Max Weber: essays in sociology, translated, edited and introduced by HH Gerth and C Wright Mills, Oxford University Press, New York. 
Westbury, N and Sanders, W 2000, 'Governance and service delivery for remote Aboriginal communities in the Northern Territory: challenges and opportunities', CAEPR Working Paper 6, Centre for Aboriginal Economic Policy Research, Australian National University, Canberra.

Wilson, J 1961, ‘Authority and leadership in a "new style” Australian Aboriginal community: Pindan Western Australia', unpublished MA thesis, University of Western Australia, Perth.

- 1980, 'The Pilbara Aboriginal social movement: an outline of its background and significance', in R Berndt and C Berndt (eds) Aborigines of the West: their past and their present, University of Western Australia Press, Perth: 151-66.

Yamatji Marlpa Barna Baba Maaja Aboriginal Corporation Annual report 2004.

Young, IM 2000, 'Hybrid democracy: Iroquois federalism and the postcolonial project', in D Ivison, P Patton and W Sanders (eds) Political theory and the rights of Indigenous peoples, Cambridge University Press, Cambridge: 237-58. 